\title{
Major Health Risk Factors in Iranian Hand-Woven Carpet Industry
}

\author{
Alireza Choobineh \\ School of Public Health and Institute of Public Health Research, \\ Tehran University of Medical Sciences, Teheran, I.R. Iran \\ Houshang Shahnavaz \\ Division of Industrial Ergonomics, Luleå University of Technology, Luleå, Sweden \\ Mohammadali Lahmi \\ School of Public Health and Institute of Public Health Research, \\ Tehran University of Medical Sciences, Teheran, I.R. Iran
}

This paper reviews the role and importance of small-scale industries together with the issue of occupational health problems and their causes in Iranian hand-woven carpet industry as a typical informal small-scale industry in an industrially developing country. The objective of this paper is to review health risk factors and related occupational health and ergonomic problems in the carpet industry. Since the overwhelming majority of weavers' health problems originate from ergonomic risk factors, it is concluded that any improvement program in this industry should focus on ergonomic aspects. To assess ergonomic conditions in weaving workshops, a checklist has been developed and an ergonomics index indicating the ergonomic conditions of the workshop has been proposed. To test and verify the checklist, 50 weaving workshops were visited and their ergonomic conditions were assessed. Based on the results some modifications were made and the checklist was shown to be an effective tool.

small-scale industries cottage industries hand-woven carpet industry industrially developing countries

\section{INTRODUCTION}

Small-scale industries are a widespread, fundamental and essential form of production [1]. In many countries, small-scale industries are the main providers of new employment. In addition, these industries play an outstanding part in economic development of countries by producing export products.

In developing countries, great efforts are directed towards encouraging the development of small-scale industries as the engine for the growth of their economies [2]. In these countries, small-scale industries employ a high percentage of the work force and comprise a high percentage of all industries. Small-scale industries have been estimated to employ $45-95 \%$ of the work force in developing countries [3]. Table 1 presents the percentage of small-scale industries and their work force in five Asian countries.

There is no internationally accepted definition of a small-scale industry [2]. In some cases, the number of employees has been the criterion for categorizing industries as a whole. Based on that, in some references, small-scale industry is defined as employing fewer than 100 [4]. France, Italy and Germany define an enterprise as small-scale if it employs fewer than 500 employees [2], whereas in Poland enterprises employing under 50 employees are categorized in this group [5]. In Iran, industries employing fewer than 10 employees are considered as

Correspondence and requests for offprints should be sent to: Alireza Choobineh, Occupational Health Department, P.O. Box 14155-6446, Tehran, I.R. Iran. E-mail: <alrchoobin@sums.ac.ir>. 
TABLE 1. Percentage of Small-Scale Industries and Their Work Force in Five Asian Countries [2]

\begin{tabular}{lccc}
\hline & \multicolumn{2}{c}{ Industries (\%) } & Work Force Employed in \\
\cline { 2 - 3 } Country & Small-Scale & Medium and Large & $\begin{array}{c}\text { Wmall-Scale Industries (\%) } \\
\text { Sm }\end{array}$ \\
\hline Hong Kong & 97 & 3 & 55 \\
Philippines & 99 & 1 & 49 \\
Singapore & 90 & 10 & 29 \\
South Korea & 93 & 7 & 23 \\
Iran & $96^{*}$ & $4^{*}$ & $85^{* *}$ \\
\hline
\end{tabular}

Notes. *-data from Hamshahri (a Persian newspaper) of June 13, 2002. **_1998 data from the Iranian Ministry of Health, Treatment and Medical Education, Center for Environment and Work Health.

small-scale industries [6]. Frijns and Van Vliet

[7] believe that among authors who have written on this issue, there is a broad agreement on the number of workers employed in a small enterprise: more than 10 and fewer that 50 workers. Enterprises employing fewer than 10 workers are called micro-enterprises. Frijns and Van Vliet [7] define small-scale industries in this way: "Small-scale industries include traditional (artisan) and informal sector micro-enterprise in addition to formal enterprises". They, therefore, believe that small-scale industries comprise both micro-enterprises (1-9 employees) and small enterprises (10-50 employees), characterized by simple manufacturing methods.

Cottage industry is a subgroup of informal small-scale industries [4]. This category is characterized by artisan and craft production, often organized around families and done in homes. In many countries, craftwork is a major part of the economy [8]. The available evidence suggests that home-based work is an important source of employment throughout the world, especially for women, and that home-based workers comprise a significant share of the workforce in key export industries [9]. Cohen and Smith [10] declare that the development of small business is vital in fostering an entrepreneurial sprit in the community. They believe that a home-based enterprise can be created to allow people to work without worrying about transportation or day care. They state that a system of home-based workers could be organized to form a functional work unit. This subject constitutes current potential of community ergonomics.

The vast majority of the labor force in south Asia is in agriculture and the informal sector. Recent official estimates suggest that over $80 \%$ of workers in low-income countries and more than $40 \%$ of workers in middle-income countries operate in informal and rural labor markets, beyond the reach of trade unions and direct government intervention [9]. Chen et al. [9] declare that in the past, the standards set by the International Labour Office (ILO) have mainly applied to the formal sector of labor, that is, to workers in large-scale, organized industries.

The preponderance of small-scale industries, in particular the informal sector and cottage industries, and their employment of a substantial percentage of the work force in developing countries necessitate great attention towards the health and safety problems of this sector [2]. Paying attention to occupational health and safety in this sector and improving working conditions, indisputably have noticeable impact on national production, economy and quality of life.

In spite of the mentioned facts and the vital importance of occupational health and safety in this sector, unfortunately, occupational health and services are practically nonexistent or, at best, minimal [2] and have been a neglected area $[4,11]$. This sector is almost exempted from workers' compensation law and other occupational safety and health regulations. In many countries, government agencies responsible for safety and health are unaware of the risks facing crafts people, and occupational 
health services do not reach out to this group of workers [8]. Much of the experience and recorded evidence indicate that the workers in small enterprises constitute an under-served population from the standpoint of their health and safety [1]. In spite of the lack of reliable quantitative data, experience has demonstrated that the characteristics of small-scale industries result in a greater likelihood of musculoskeletal injuries, accidents and poisoning [1].

\section{COTTAGE INDUSTRY IN IRAN}

In Iran small-scale industries comprise $96 \%$ of industries and employ a large proportion of work force (Table 1). Handicraft is a major section in this sector such that its share in the Gross National Product (GNP) is equal to $3 \%$. This share in comparison to the share of automotive industries and petrochemical industries in GNP (2.7 and $2 \%$, respectively) is quite noticeable [12]. In Iran carpet hand-weaving has the first rank from the viewpoint of importance and size among other handicrafts. Hand-woven carpets are the most important Iranian non-oil export product and they have an outstanding place in the country's economy because of their share of $1 \%$ in GNP [13] and employment. In Iran, there are nearly 2.2 million full- and part-time weavers [14] and about 8.5 million people directly or indirectly live from the hand-woven carpet industry [15]. In 1999, carpet export comprised over $20.5 \%$ of the total non-oil export of the country [13].

Factors that are usually considered in setting priorities for health services are (a) the size of the population at risk and the degree of morbidity and (b) the extent to which a particular program contributes to overall socioeconomic development, its effectiveness, feasibility, cost, and relative urgency [3]. Considering these factors for setting priorities in occupational health practices, and taking into consideration:

- widespread carpet industry in the country,

- the economic importance of the carpet industry,
- the role of carpet industry in generating employment,

- the socio-cultural value of carpet industry,

it can be concluded that in Iran, attention to the weavers' occupational health and improvement of their working conditions should be among the list of practices with high national priority. It undoubtedly has considerable effects on national production, economy, quality of life and sustainable development.

The present paper studies occupational health and ergonomic problems in the carpet industry. The objectives of this paper are to review health risk factors and related occupational health and ergonomic problems in the carpet industry, to develop a checklist for an ergonomic evaluation of working conditions and the environment and to produce an ergonomics index, indicating current ergonomic conditions in a weaving workshop. It is believed that this can be regarded as the first step towards improving working conditions in this industry.

\section{WORKING CONDITIONS IN THE CARPET INDUSTRY}

Hand-woven carpets are mainly produced in home-based workshops and in limited cases in a weaving complex, where a number of weavers are gathered and where they weave carpets [16]. A carpet loom is the most important element of the weaving operation, which is divided into two types, horizontal and vertical. Horizontal looms pose a number of hazards. The weaver has to squat on these looms with severely deviated and harmful postures of the neck, back and legs, which can result in deformity in the back and hip bones and other kinds of musculoskeletal problems (Figure 1). Vertical looms, which are recognized as safer than horizontal ones, create problems too. Sitting on the bench or ground, weavers perform their jobs. Vertical looms are different in type. The seat depends on the loom type. In some cases the ground is the seat and weaving is done in a cross-legged posture. Sometimes the seat 
consists of a piece of lumber as seen in Figure 2. In this case there is not enough leg room between the loom and the seat for leg movement and legs are trapped in this enclosed space [16]. In fixed vertical looms, with progress of weaving, the weaving height comes up. In this situation, in order to adjust the seat, the weaver has to place it in a higher position. The result is that the seat is high and the weaver's legs dangle. Sometimes, to prevent legs from dangling, the weaver sits cross-legged on the seat. In some cases the seat is covered with soft materials, but in other cases it is not. Vertical looms currently dominate [16].

While weaving a carpet, threads in the loom are held with the non-dominant hand, and with the

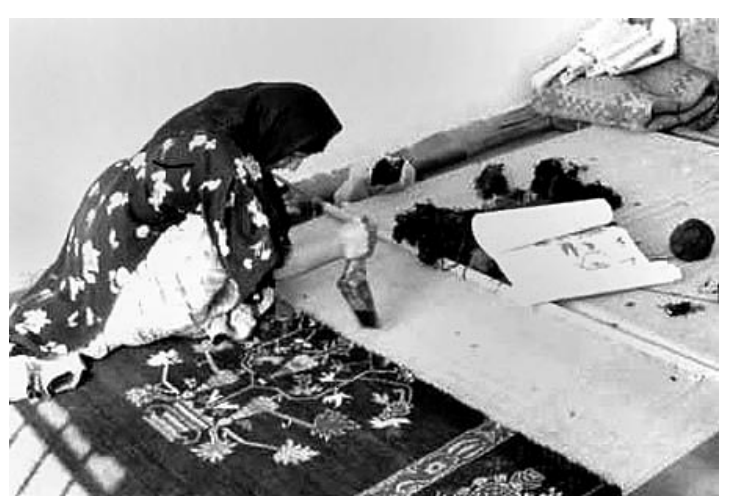

Figure 1. A woman is weaving at a horizontal loom. She is sitting on the loom. Her neck, back, and legs postures are awkward and severely deviated from neutral postures.

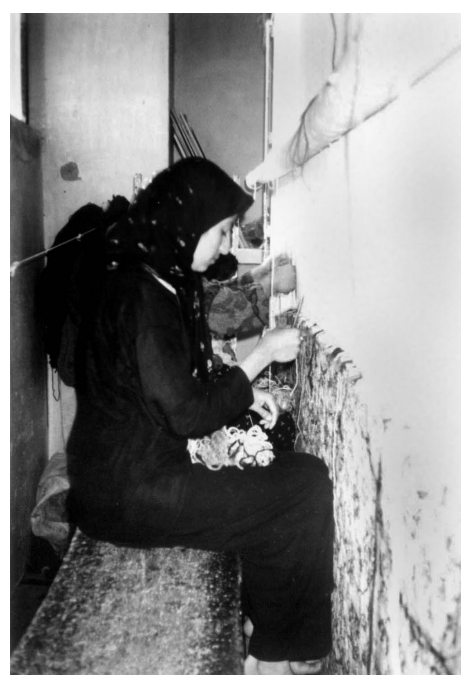

Figure 2. A girl is weaving at a vertical loom. In front of her legs, there is not enough clearance for free leg movements. The seat is a wooden flat piece of lumber without padding. dominant hand another thread is passed between the loom threads and is knotted. Afterwards the tip of the knot is cut with a knife, which is held in the dominant hand. After two or three rows of knots, they are compressed with an iron comb and, to obtain a smooth surface, the threads are cut with scissors. Hand tools used in carpet weaving are traditionally designed and no ergonomics is applied in their structures. Due to the poor design of weaving hand tools and inappropriate material used in their structures, parts of weavers' hands and fingers bear contact stress which may cause hand soft tissue injury. Figure 3 shows some hand tools used in a carpet hand-weaving operation. In Figure 4 the effect of using hand tools on the weaver's hands are shown. In some cases, the comb is heavy and compressing the knots, which is considered as a repetitive movement, increases the risk of upper arm and shoulder musculoskeletal problems.

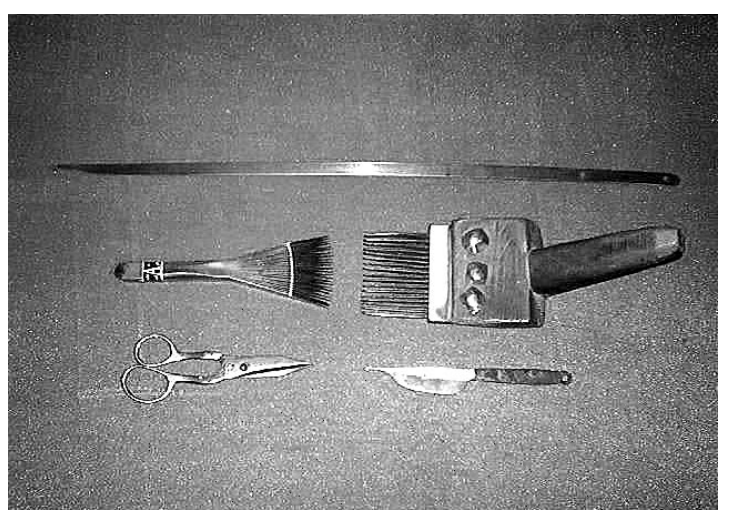

Figure 3. Some hand tools used in carpet handweaving operations. Notes. Top-weaving skewer, middle-two weaving combs, bottom-weaving scissors and a weaving knife.

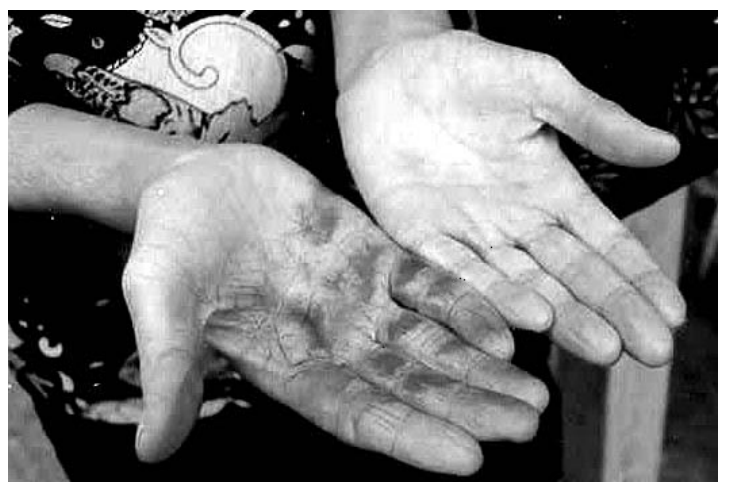

Figure 4. Soft tissue impacts on a weaver's hand caused by contact stress due to ill-designed hand tools. 
Raw materials used in carpet weaving are mainly wool and threads. Sometimes these materials have low quality or are infected with biological agents and they produce health problems for weavers [17, 18, 19].

Weaving workshops, which are mainly home-based, are small in size and generally lack adequate lighting, ventilation, cooling and heating systems. Weavers, who are mostly women [20], have low income and their education is mostly at primary level. Working hours in the carpet industry are not fixed and they vary based on the situation and workload, however, motivation towards earning more money causes weavers to work longer [16]. Carpet weaving at home is divided into two different systems of production [20]: (a) independent production in which weavers produce carpets through their own investments and family labor, and (b) contract production, which is divided into two types. In the first type, the merchant and the weaver agree on a production plan without the merchant providing raw materials. In the second type, the merchant provides raw materials to the weaver. In the contract production system the weaver agrees to finish the work by a certain deadline. In independent production, there is no time limit. System (a) is believed to be more common [21].

\section{HEALTH RISK FACTORS IN THE CARPET INDUSTRY}

Carpet weaving is one of the most tedious professions, requiring long hours of static work [20]. McCann [4] divides health hazards in the carpet industry into two categories, namely ergonomic risk factors and toxic chemicals. Based on the studies conducted on this area, it can be stated that carpet hand-weaving is a high risk occupation for developing musculoskeletal problems, skin diseases, respiratory diseases and impaired vision. Based on that, health risk factors can be categorized into ergonomic risk factors covering musculoskeletal disorders, eyesight disorders and hygienic risk factors including skin and respiratory diseases.

\subsection{Ergonomic Risk Factors in the Weaving Profession}

\subsubsection{Awkward posture}

Due to poor design of hand tools, weaving workstation and looms, postures of the neck, back, shoulder, upper and lower arms, wrists and knees are deviated from a neutral position and are harmful. In a study on 1,020 weavers, Choobineh et al. [16] found the percentage of weavers who adopted deviated postures in different body parts including upper arm, lower arm, neck, trunk and leg to be 88.6, 57.6, 82.8, 85.9 and $69.5 \%$, respectively.

There is no leg clearance when using vertical looms, which causes the weaver to work in a cross-legged or fixed leg posture [16]. In this situation, because there is no space for leg movements, the weaver can not displace postural stress over different regions of the lower extremities. This causes the worker not to be able to vary posture and reduce fatigue [22]. Figures 2 and 5 show the leg posture of weavers.

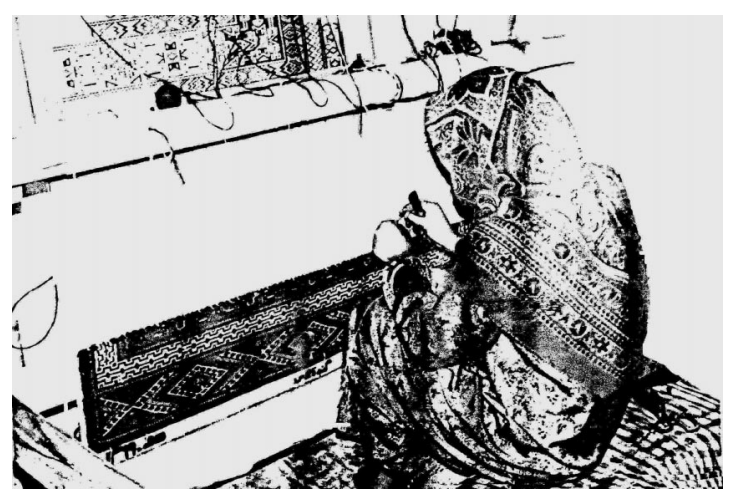

Figure 5. A girl is weaving at a vertical loom. She is sitting on the ground with her knees folded.

In some cases, it is observed that the weaving height is too high, causing shoulder and upper arm flexion and deviation from neutral postures (Figure 6). In traditional looms because there is no workstation adjustability, weaving height adjustment is difficult and it is the main cause of 


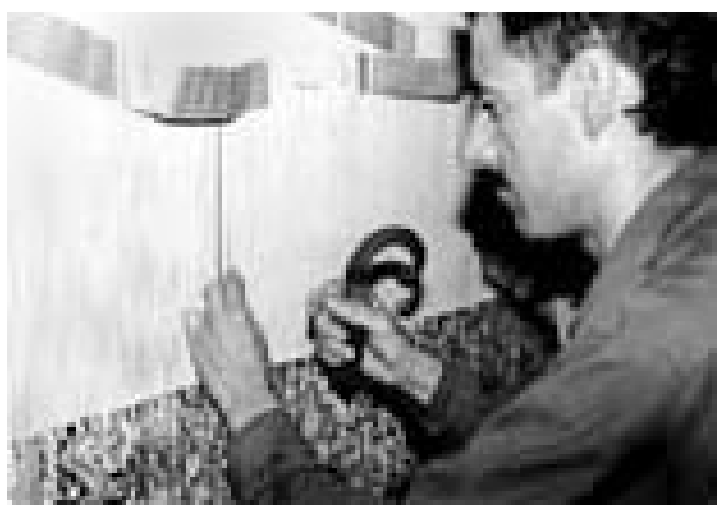

Figure 6. A man is weaving at a loom. Weaving height is high causing shoulder flexion. Shoulder and upper arm postures are deviated from neutral.

the awkward postures of the upper limbs. In some cases, the weaver adjusts the weaving height so low (at sitting elbow height or even lower). This results in better shoulder, upper and lower arms postures, but causes sever neck and back inclination. The weaver has to keep on working in this harmful posture until some rows of knots have been woven and the height of weaving comes up. This situation sometimes takes days or even weeks. In horizontal looms in which the weaver sits on the horizontal loom and weaves (Figure 1), neck, back and lower extremities postures are severely awkward.

Awkward postures of wrists and fingers during weaving are mainly due to poor hand tool design and the nature of the tasks. Wrist extension/flexion while cutting the knots with a knife, ulnar and radial deviations during combing and compressing the knots, and forearm supination/pronation are commonly observed in carpet weaving.

\subsubsection{Repetitive movements}

Weaving is actually a highly repetitive task, in which a regular weaver makes up to 30 knots per minute. During all steps of weaving, the wrist and finger flexors and extensors are used repetitively, with pinching movements and force grasping [23]. If it is assumed that the weaver works for $8 \mathrm{hrs}$ a shift and the weaving task comprises $60 \%$ of the total working time, there will be 8,640 knots per shift. It can, therefore, be concluded that in weaving, repetitive movement is common. Since highly repetitive tasks have cycle lengths of $30 \mathrm{~s}$ or less [24], weaving is categorized as a highly repetitive job.

\subsubsection{Contact stress}

Due to the poor design of weaving hand tools and inappropriate material used in their structures (Figure 3), parts of weavers' hands and fingers bear contact stress, which may cause injury of hand soft tissue (Figure 4).

\subsubsection{Force exertion}

The weight of a weaving comb, in some cases, is more than $2 \mathrm{~kg}$. Since in carpet weaving at certain intervals the weaver has to compress the knots by using the comb, its heavy weight and repetitive application can result in upper limb disorders.

\subsubsection{Inadequate lighting}

Carpet weaving operation is considered as a precision work, for the knots are very fine and close together, and color recognition is of vital importance. Such operations require adequate lighting both qualitatively and quantitatively. In many weaving workshops, lighting is not adequate, which results in considerable eyestrain [17]. Choobineh [21] measured the average illumination level in 1,020 weaving workstations. He found inadequate illumination with the average of $286 \mathrm{~lx}(S D=290.7)$ in the weaving workshops studied.

Besides eyestrain, insufficient lighting results in awkward posture, for weavers incline their heads, necks and backs to be able to look closer at their work.

\subsubsection{Improper climate}

Lack of cooling and heating systems in weaving workshops, which have low income, results in improper thermal conditions. Choobineh [21] subjectively evaluated thermal conditions in 
weaving workshops. The result is presented in Table 2. As seen, nearly $50 \%$ of weavers perceived the thermal condition as very warm, warm and slightly warm in summer time and about $47 \%$ of them perceived the thermal condition as very cold, cold and slightly cold during winter time. Improper climate will have adverse effects on the well-being of the weavers and consequently on their performance.

TABLE 2. Weavers' (\%) Perception About Thermal Conditions of Weaving Workshops Studied (n 1020)

\begin{tabular}{lcccc}
\hline \multicolumn{5}{c}{ Summer Time } \\
\hline $\begin{array}{l}\text { Very } \\
\text { Warm }\end{array}$ & Warm & $\begin{array}{c}\text { Slightly } \\
\text { Warm }\end{array}$ & Neutral & Cool \\
\hline 8.8 & 28.9 & 13.1 & 36 & 13.1 \\
\hline
\end{tabular}

\begin{tabular}{ccccc}
\hline \multicolumn{5}{c}{ Winter Time } \\
\hline $\begin{array}{c}\text { Very } \\
\text { Cold }\end{array}$ & Cold & $\begin{array}{c}\text { Slightly } \\
\text { Cold }\end{array}$ & Neutral & Warm \\
\hline 11.5 & 23.1 & 12.4 & 39.4 & 13.6 \\
\hline
\end{tabular}

\subsubsection{Lack of rest pause}

Because of no scheduled working time, usually weavers work continuously for a long time without rest pauses. This causes prolonged exposure to occupational risk factors and increases risk of disorders.

\subsection{Hygienic Risk Factors in the Weaving Profession}

\subsubsection{Contaminated ambient air}

In the operation of wool preparation, combing knots and cleaning the workshop, wool fibers are produced and released into the atmosphere. Lack of proper ventilation in the workshop causes the weaver to be exposed to those fibers and increases risk of respiratory diseases. Contamination of fibers with biological agents such as bacteria and fungi results in respiratory exposure to these agents and threatens the health of the weaver $[17,20,25,26,27,28]$.

\subsubsection{Toxic hazards}

Some dyestuffs used in wool preparation are toxic (e.g., chromate-based chemicals). Skin exposure to such toxic chemicals causes skin diseases and dermatitis [17]. Biological agents such as anthrax bacillus can enter the body and produce infectious skin diseases, as well.

\section{OCCUPATIONAL HEALTH PROBLEMS IN THE CARPET INDUSTRY}

In spite of the national importance of the carpet industry in Iran and its economic potential, there have been few occupational health and ergonomics studies on weavers' work. Based on the previous section, weaving occupational health problems can be divided into ergonomic and hygienic problems.

\subsection{Ergonomic Problems}

Major health problems in the carpet industry arise from ergonomic risk factors, particularly awkward working postures. The number of studies conducted on work-related musculoskeletal disorders (WMSDs) in the carpet industry in comparison to other areas is relatively high. Figure 7 presents the prevalence of WMSDs symptoms in different body regions of weavers over a period of 12 months [16]. Abnormality and deformity of the back bone, arms, legs and pelvis are among reported WMSDs among weavers [17, 20, 29]. Studies indicate that deformation of the pelvis, often in a restricted form, necessitates Caesarian section for pregnant women weavers [17, 20, 30]. Merasy [31] reported the prevalence of severe pain in weavers' back bone to be $35.5 \%$. He found the prevalence of leg, thigh and joints problems to be $23.3 \%$ among weavers. In another study the prevalence of back, shoulder and knees problems among weavers was found to be $59 \%$ 
[32]. Mazloomi [33] declared that the prevalence of skeletal pain among weavers was $36.5 \%$. He found that most and fewest complaints were related to the back and neck, respectively. Alamanos et al. [34] showed that there was a statistically significant association between the intensity of symptoms from upper extremities and the shoulder-neck region and the number of years of working at the loom. In this study the prevalence of musculoskeletal symptoms among women weavers were $46.2 \%$ for the back, $32.9 \%$ for upper extremities and $23.9 \%$ for lower extremities. Das et al. [26] also reported ergonomic problems such as back pain and joints pain among Indian weavers.

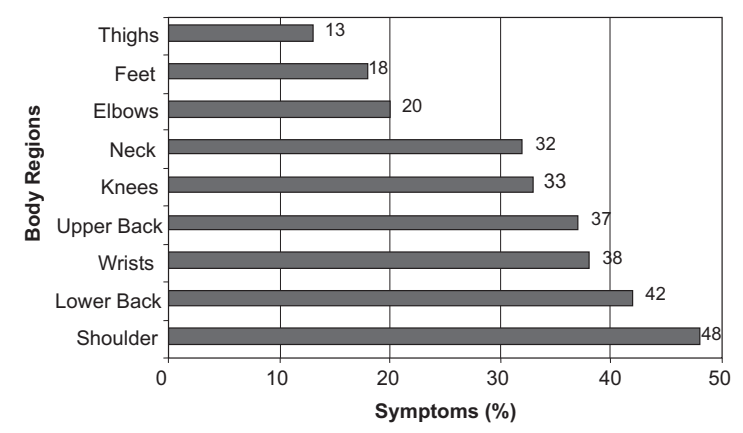

Figure 7. Reported symptoms in different body regions of weavers during the previous 12 months $(n \sim 1020)$.

In these studies, researchers used different definitions for defining musculoskeletal problems, that is why it is not possible to compare the results.

Wrist, hand and finger problems are other prevalent WMSDs among weavers. Kutluhan et al. [23] believed that hand-made carpet weavers were exposed to varying degrees of repetitive and forceful hand and wrist motions and they appeared to be at increased risk for the development of hand and arm musculoskeletal symptoms and the carpal tunnel syndrome (CTS). They concluded that weaving was a high risk profession for upper extremity repetitive strain and CTS. Radjabi [17] declared that constant tying of knots might result in swollen finger joints, arthritis and neuralgia, causing permanent deformation of fingers. Choobineh et al. [16] found the prevalence of wrist and hands symptoms among weavers to be $38 \%$ (Figure 5). The results of their study showed that $17 \%$ of weavers had lost working days due to wrist and hand problems during the preceding year. Researchers proved that in weaving operations because of the continuous use of wrists, fingers and repetitive movements, the risk of injuries of wrist and hand soft tissue, particularly of the median nerve, is high [35, 36, 37].

Eyesight disorders are prevalent among weavers because of eyestrain and inadequate lighting [17]. Ghvamshahidi [20] declared that the average working life cycle of a highly skilled weaver is estimated at 13 years since weavers lose their eyesight, in part, due to improper lighting. Radjabi [17] presented cases of almost total blindness occurring after 12 years of employment at this work. In his research, Kavoussi [38] studied the relationship between the length of employment in carpet weaving and vision impairment. In this research, $63.5 \%$ of weavers had impaired vision. He concluded that long employment in carpet weaving impairs visual acuity.

\subsection{Hygienic Problems}

In the weaving profession some occupational diseases are caused by hygienic risk factors. Lack of fresh air in the weaving workshop and the presence of wool fibers together with bioaerosols in the ambient air can result in various lung diseases and a reduction in respiratory vital capacity [17, 20, 25, 26, 27, 28]. Namaki [39], in his study, found that tuberculosis was more prevalent in weavers than non-weavers. Radjabi [17] believed that anthrax infection caused by raw wool was a prevalent disease among weavers. Dehghani Ghanateghestani [19] studied skin fungous infections in weavers. He showed that workshops' ambient air and raw materials were contaminated with diverse species of fungi and in some cases there were skin infections in weavers. Due to toxic chemical dyestuffs and biological agents, dermatitis and skin diseases are other health problems weavers deal with $[17,20]$. 


\section{A CHECKLIST FOR AN ERGONOMIC EVALUATION OF HAND-WOVEN CARPET PRODUCING WORKSHOPS}

The checklist is structured to cover ergonomic problems that exist in weaving workshops. It should also be possible to use it quickly and easily by the weavers themselves or people with minimum training and resources. The checklist integrates available knowledge and provides a systematic ergonomic assessment tool for weaving workshops. It can also be used to produce a list of priorities for upgrading working conditions. It is believed that using this checklist can increase ergonomics awareness of both weavers and inspectors.

In the development of the checklist, issues of general working conditions (GWC), workstation design and adjustability (WD), working posture (WP) and hand tools (HT) have been the criteria of particular importance for evaluation.

In the devising process, different checklist references, including ILO checkpoints [40], Helander [41], Richard [42], and the Finnish Institute of Occupational Health [43], were consulted, together with available knowledge concerning major health risk factors in carpet hand-weaving operations.

The ergonomics index indicates the present ergonomic conditions. The ergonomics index (a percentage) may vary from 0 to $100 \%$. A high ergonomics index indicates good ergonomic conditions. The ergonomics index helps to identify needs for improvement, to set corrective measures and to measure the results of ergonomic actions.

All items of the checklist are observed at workstations. An item is assessed to be either provided (yes) or not provided (no). An item is scored 1 if it is provided (yes) and 0 if it is not provided (no).

The ergonomics index is calculated as a percentage of all provided items in the checklist. An index can be calculated for each part of the checklist to identify the major sources of problems and ergonomic bottlenecks in the workplace.

GWC index $=\frac{\text { GWC score }}{13} \times 100(\%)$

WD index $=\frac{\text { WD score }}{9} \times 100(\%)$

WP index $=\frac{\text { WP score }}{9} \times 100(\%)$

HT index $=\frac{\text { HT score }}{6} \times 100(\%)$

ergonomics index $=\frac{\text { total score }}{37} \times 100(\%)$

As a tool for improving working conditions, the ergonomics index is interpreted in accordance to the action categories described in Table 3 .

TABLE 3. Action Categories (AC) for the Improvement of Working Conditions

\begin{tabular}{lcc}
$\begin{array}{l}\text { Ergonomics } \\
\text { Index }\end{array}$ & AC & $\begin{array}{c}\text { Poor Ergonomic } \\
\text { Conditions }\end{array}$ \\
\cline { 1 - 2 } $0-25$ & 4 & \\
$26-50$ & 3 & \\
$51-75$ & 2 & $\begin{array}{c}\text { Good Ergonomic } \\
\text { Conditions }\end{array}$ \\
$76-100$ & 1 &
\end{tabular}

Notes. In all cases attention should be focused on priorities, with corrective measures required as soon as possible. 4-Further investigation is needed. Corrective measures are required soon. 3-Further investigation is needed. Corrective measures are required. 2-Further investigation is needed. Corrective measures may be needed. 1-Working conditions are acceptable.

In order to test and verify the checklist, 50 weaving workshops were visited and their ergonomics conditions were assessed using the checklist. The result of the assessment is presented in Table 4. It shows that workstations and working postures are the major sources of problems in workshops: the means of workstation and working posture indices are $29.1 \%$ and $30 \%$, respectively. This is in total accordance with the authors' experience and previous studies on the ergonomics conditions in weaving workshops. Based on the results, working conditions in $2 \%$ of the workshops are acceptable (action category 1). Working 
conditions in $60 \%$ of the workshops fall in action category 2 . So, the interpretation is that in these workshops further investigation is needed and corrective measures may be required for the improvement of working conditions. In $38 \%$ of the workshops visited working conditions are worse so that they fall within action category 3 . This means that corrective measures are required and working conditions should be improved. As the results indicate, improvements should focus on workstation design and the working posture.

TABLE 4. Ergonomic Assessment of Weaving Workshops With the Developed Checklist $(n=50)$

\begin{tabular}{lccc}
\hline Index & $\boldsymbol{M}$ & $\boldsymbol{S D}$ & Min-Max \\
\hline $\begin{array}{l}\text { General } \\
\text { conditions }\end{array}$ & 65.1 & 16.4 & $30.8-92.3$ \\
$\begin{array}{l}\text { Workstation } \\
\text { Working }\end{array}$ & 29.1 & 10.5 & $11.1-55.6$ \\
$\quad$ posture & 30.0 & 15.1 & $0-66.7$ \\
Hand tools & 81.7 & 5.1 & $66.7-83.3$ \\
Ergonomics & 51.6 & 10.8 & $29.7-86.5$ \\
\hline
\end{tabular}

In general, the results showed that the checklist was an appropriate tool for an ergonomic assessment in weaving workshops. However, it required minor verification and modification. The verified checklist is presented in Table 5 .

\section{DISCUSSION}

In developing countries, the scale of use of human resources in small-scale labor-intensive industries is enormous. In this situation, it must be obvious that very small improvements in working conditions, implements, tool design or working methods can lead to large benefits [44]. It is believed that occupational health programs in developing countries should focus more on the informal sector, which employs a large proportion of workers [45]. Paying attention to occupational health and safety in this sector and improving working conditions will undoubtedly have considerable impact on the national economy and the quality of people's life. Unfortunately, the traditional approach to occupational health has tended to concentrate mostly on factory and mine workers in urban industrial settings and has neglected occupationally-related health problems in informal or unregulated sectors where the majority of many developing countries' population live and work [46]. This is so in spite of the fact that this sector is more vulnerable to musculoskeletal injuries, accidents and poisoning. This traditional approach should be changed as experience and evidence have proved the importance of small-scale industries in

TABLE 5. An Ergonomics Checklist for Enhancing Comfort, Health and Performance in a Carpet HandWeaving Operation

\begin{tabular}{lllll}
\hline & \multicolumn{3}{c}{ Responses } \\
\cline { 2 - 3 } Questions & Yes & No & Priority & Remarks \\
\hline
\end{tabular}

\section{GENERAL CONDITIONS}

\section{Lighting}

Is sufficient day light used in the workshop?

Are light colors used for walls and ceilings?

Is the level of illumination on the weaving point sufficient (minimum 500 lx)?

Are the windows and light sources clean?

Is harmful direct glare from illumination sources or windows absent?

Are the operators' eyes free from indirect (reflected) glare?

Is the general contrast in the visual field acceptable? 


Questions
Thermal conditions
Is the air temperature suitable for the activity $\left(21-25^{\circ} \mathrm{C}\right)$ ?
Is the humidity suitable $(40-60 \%) ?$
Is the air velocity suitable and with no draft?

\section{Air quality}

Is the air clean and healthy (without airborne contaminants such as dust, fibers and bioaerosols)?

Is natural ventilation used to improve the indoor climate when needed?

Is the workshop regularly cleaned and housekept?

\section{WORKSTATION}

Is the loom vertical?

Are primary items located within easy reach of the weaver?

Is there enough free space for legs under the loom?

Can the weavers adjust their workstations dimensions to fit them?

Is the adjusting mechanism easy to handle?

Is the weaving height adjustable so that the weavers can adopt healthy postures?

Is the chair comfortable?

Is the height of the chair easily adjustable?

Does the chair have a backrest?

\section{WORKING POSTURE}

Are the hands at a convenient working height for the task so that the elbow angle ranges from $60^{\circ}$ to $100^{\circ}$ ?

Are the upper arms mostly in a convenient neutral posture so that there is no shoulder flexion?

Are the joints mostly in a convenient neutral position (nearly in the midpoint of their range of motion)?

Can the weaver adopt several healthy postures while working?

Can the task be performed with the trunk upright and the neck slightly inclined forward $\left(<20^{\circ}\right)$ ?

Are the feet supported on the floor or on a footrest?

Do weavers take frequent short breaks to reduce the soreness and stiffness related to fixed, static work postures?

Do weavers stretch during their breaks to reduce the soreness and stiffness related to fixed, static work postures?

Are weaver provided with eye examinations and proper eyeglasses, if needed? 


\begin{tabular}{lllll}
\hline & \multicolumn{3}{c}{ Responses } \\
\cline { 2 - 3 } Questions & Yes & No & Priority & Remarks \\
\hline
\end{tabular}

\section{HAND TOOLS}

Are hand tools comfortable and safe to use?

Is the size of the handles designed in accordance with the anthropometric dimensions of weavers' hands?

Are sharp edges and pinch points avoided in hand tools?

Are the form and the position of the handles of hand tools designed for convenient grip?

Is the handle of the tool made from materials other than metal?

Is the weight of the weaving comb acceptable to the weaver?

diverse socio-economical aspects and sustainable development.

In Iran, hand-woven carpet industry, as an informal small-scale industry, employs a large work force. Like other informal small-scale industries around the world, this industry also faces occupational health problems and weavers have been an under-served population. Most health problems in this sector originate from ergonomic risk factors. Any improvement program in this industry should, therefore, focus on the ergonomic aspects of hand-weaving operation. The checklist and ergonomics index presented in this paper can be applied to assess working conditions in weaving workshops as the first step in identifying major ergonomic problems and setting priorities and corrective measures. Application of the developed checklist for ergonomic assessment in 50 weaving workshops revealed that it was an effective tool in identifying ergonomic bottlenecks in weaving workshops (Table 5).

\section{REFERENCES}

1. Glass B. Small enterprises and occupational health and safety. In: Stellman JM, editor. Encyclopaedia of occupational health and safety. 4th ed. Geneva, Switzerland: International Labour Office; 1998. vol. I, p. 20.8-10.
2. Reverente BR. Occupational health services for small-scale industries. In: Jeyaratnam J, editor. Occupational health in developing countries. New York, NY, USA: Oxford University Press; 1992. p. 62-88.

3. Noweir MH. Occupational health in developing countries with special reference to Egypt. Am J Ind Med 1986;9:125-41.

4. McCann M. Hazards in cottage industries in developing countries. Am J Ind Med 1996;30:125-129.

5. Derlicka M, Shahnavaz H. Working conditions in small private enterprises in Poland. JOSE 2000;6(1):129-43.

6. Sanaat and Maadan Bank. Small-scale industry strategy and essential of small-scale industry bank establishment in the country. Teheran, Iran; 2001. In Persian.

7. Frijns J, Van Vliet B. Small-scale industry and cleaner production strategies. World Development 1999;27(6):967-83.

8. McCann M. Entertainment and the arts. In: Stellman JM, editor. Encyclopaedia of occupational health and safety. 4th ed. Geneva, Switzerland: International Labour Office; 1998. vol. III, p. 96.2-7.

9. Chen M, Sebstad J, O'Connell L. Counting the invisible workforce: the case of home-based workers. World Development 1999;27(3):603-10. 
10. Cohen WJ, Smith JH. Community ergonomics: past approaches and future prospects towards America's urban crisis. In: Proceedings of the Human Factors and Ergonomics Society 38th Annual Meeting: Vol. 2. Nashville, Tennessee, October 24-28, 1994. Santa Monica, CA, USA: Human Factors and Ergonomics Society; 1994. p. 734-8.

11. Jafry T, O'Neill DH. The application of ergonomics in rural development: a review. Appl Ergon 2000;31:263-8.

12. 2.2 millions employed in handicrafts sector. Economic information [newspaper] 2002; 22499: 1. In Persian.

13. Mahdavi H. (2000). What should be done for Iranian carpet export? Kayhan [a newspaper] 2000;16940:5. In Persian.

14. Sobhe K. A research in international market of Iranian carpet and its export development. Iran Hand-woven Carpet Magazine 1997;10:31-46. In Persian.

15. Jihad-Sazandegi Organization. Carpet weavers' health. Zanjan, Iran: Solaleh; 1998. In Persian

16. Choobineh A, Lahmi MA, Hosaini M, Jamali M, Rezaee Gorji Z. (2003). Musculoskeletal problems and corrective measures in Iranian hand-woven carpet industry. In: Proceedings of the XVth Triennial Congress of the International Ergonomics Association and the 7th Joint Conference of Ergonomics Society of Korea/Japan Ergonomics Society. Seoul, Korea: Ergonomics Society of Korea. vol. 7, p. 270-3.

17. Radjabi A. Carpets, hand-woven. In: Encyclopaedia of occupational health and safety. 3rd ed. Geneva, Switzerland: International Labour Office; 1983. vol. I, p. $416-8$.

18. McCann M. Artist beware. 2nd ed. New York, NY, USA: Lyons \& Burford; 1992.
19. Dehghani Ghanateghestani A. Study of mycological infections in Kerman weavers [Master of Science thesis, 2308]. Tehran, Iran: School of Public Health, Tehran University of Medical Sciences; 1994. In Persian.

20. Ghvamshahidi Z. The linkage between Iranian patriarchy and the informal economy in maintaining women's subordinate roles in home-based carpet production. Womens Stud Int Forum 1995;18(2):135-51.

21. Choobineh A. Development of an ergonomic carpet weaving workstation with emphasis on neutral working posture based on field survey and laboratory interventions [doctoral dissertation]. Tehran, Iran: Department of Occupational Health, School of Public Health, Tehran University of Medical Sciences; 2004. In Persian.

22. Clark DR. Workstation evaluation and design. In: Bhattacharya, A, McGlothlin JD, editors. Occupational ergonomics: theory and practice. New York, NY, USA: Dekker; 1996. p. 279-301.

23. Kutluhan S, Akhan G, Demirci S, Duru S, Koyuncuoglu HR, Ozturk M., Cirak B. Carpal tunnel syndrome in carpet workers. International Archive of Occupational Health 2001;74:454-7.

24. Tayyari F, Smith JL. Occupational ergonomics, principles and applications. London, UK: Chapman \& Hall; 1997.

25. Ozesmi M, Aslan H, Hillerdal G, Rylander $\mathrm{R}$, Ozesmi C. Byssinosis in carpet weavers exposed to wool contaminated with endotoxin. Br J Ind Med 1987;44:479-83.

26. Das PK, Shukla KP, Ory FG. An occupational health programme for adults and children in the carpet weaving insudtry, Mirzapour, India: a case study in the informal sector. Soc Sci Med 1992;35(10): 1293-302.

27. Joshi SK, Sharma P, Sharma U, Sitaraman S, Pathak SS. Peak expiratory flow rate of 
carpet weaving children. Indian Pediatr 1996; 33(2):105-8.

28. Shamssain MH, Shamssian N. Respiratory symptoms and pulmonary function group of women weavers in South Africa. Ann Hum Biol 1997;24(4):299-306.

29. Barazani GC. Fiber and textile carfts. In: Stellman JM, editor. Encyclopaedia of occupational health and safety. 4th ed. Geneva, Switzerland: International Labour Office; 1998. vol. III, p. 96.14-6.

30. Tajadod H. Ergonomics in the carpet industry [Master in Public Health thesis]. Tehran, Iran: School of Public Health, Tehran University; 1971. In Persian.

31. Merasy MR. Prevalence of skeletal disorders based on individual and environmental characteristics in Najafabad's weavers from 1993 to 1994 [Master of Science thesis, 2305]. Tehran, Iran: School of Public Health, Tehran University of Medical Sciences; 1994. In Persian.

32. Fotohabadi MR. Prevalence of musculoskeletal disorders among Fasa's weavers. In: Proceedings of the 8th Iran physiotherapy congress. Tehran, May 12-14 1997. Tehran, Iran: Iranian Physiotherapy Society; 1997. p. 13-5. In Persian.

33. Mazloomi SS. Study of weavers health conditions in Yazd province villages. In: Proceedings of Bagha program conference and workshop. Tehran, November 23-24. Tehran, Iran: Ministry of Jihad-Sazandegi; 1996. p. 31-43. In Persian.

34. Alamanos Y, Tsamandouraki K, Koutis A, Fioretos M. Working at the loom and musculoskeletal disorders in a female population of Crete, Greece. Scand J Soc Med 1993;21(3):171-5.

35. Senveli ME, Turker A, Arda MN, Altinors MN. Bilateral carpal tunnel syndrome in a young carpet weaver. Clin Neurol Neurosurg 1987;89(4):281-282.
36. Tan M, Tan U. Correlation of carpal tunnel size and conduction velocity of the sensory median and ulnar nerves of male and female controls and carpet weavers. Percept Mot Skills 1998;87:1195-201.

37. Budak F, Yenigun N, Ozbek A, Orhan S, Komsuoglu S. Carpal tunnel syndrome in carpet weavers. Electromyogr Clin Neurophysiol 2001;41:29-32.

38. Kavoussi N. An occupational health study in the carpet industry in Kerman, Iran. Work Environ Health 1973;10:48-51.

39. Namaki S. Study of occupational diseases in Kashan weavers [Medical Doctor thesis]. Isfahan, Iran: Faculty of Pharmacology, Isfahan University; 1986. In Persian.

40. International Labor Office (ILO). Ergonomic checkpoints. Geneva, Switzerland: Author; 1999.

41. Helander M. A guide to the ergonomics of manufacturing. London, UK: Taylor and Francis; 1995.

42. Richard D. Appendix B: Ergonomics checklists, section I. In: Bhattacharya A, McGlothlin JD, editors. Occupational ergonomics: theory and practice. New York, NY, USA: Dekker; 1996; p. 783-805.

43. Finnish Institute of Occupational Health. ELmeRi: a workplace safety and health observation method. Helsinki, Finland: Occupational Safety Inspectorate; 2000.

44. Sen RN. Application of ergonomics to industrially developing countries. Ergonomics 1984;27(10):1021-1032.

45. Kromhout H. Occupational hygiene in developing countries: something to talk about? Ann Occup Hyg 1999;43(8):501-3.

46. Christiani DC, Durvasula R, Myers J. Occupational health in developing countries: review of research needs. Am J Ind Med 1990;17:393-401. 